\title{
Strategi kampanye Alzheimer Indonesia \#janganmaklumdenganpikun dalam membangun kesadaran akan isu demensia
}

\author{
Joel Immanuel ${ }^{1}$, El Chris Natalia ${ }^{2}$ \\ ${ }^{1,2}$ Universitas Katolik Indonesia Atma Jaya, Jakarta, Indonesia
}

\begin{abstract}
ABSTRAK
Alzheimer Indonesia (ALZI), salah satu organisasi nonprofit membuat sebuah kampanye sosial dengan tema \#JanganMaklumDenganPikun (\#JMDP) dalam membangun kesadaran masyarakat. Tujuan dari kampanye yang dilakukan oleh ALZI adalah untuk meningkatkan kesadaran masyarakat mengenai penyakit demensia yang tidak bisa dianggap sebagai hal remeh. Pikun tidak lagi menjadi sesuatu hal yang biasa karena dapat menjadi salah satu tanda atau gejala dari penyakit demensia. Penelitian ini membahas mengenai strategi kampanye yang dilakukan oleh Alzheimer Indonesia (ALZI) dengan tema \#JanganMaklumDenganPikun dalam membangun kesadaran terhadap isu demensia. Penelitian berfokus pada program Summer School Fakultas Kedokteran, Universitas Katolik Indonesia Atma Jaya. Kampanye \#JMDP dirancang dengan berdasarkan pada isu mengenai kurangnya kesadaran masyarakat akan penyakit demensia. Pada penelitian ini teori yang digunakan yaitu Public Relations, Kampanye, Strategi Kampanye Publik dengan fokus pada model kampanye Ostergaard, Isu, dan Komunikasi Kesehatan. Metode dalam penelitian ini menggunakan jenis penelitian kualitatif dengan pendekatan analisis deskriptif. Teknik pengambilan data dilakukan dengan menggunakan dua cara, yaitu wawancara mendalam dan studi dokumentasi. Hasil penelitian menunjukkan bahwa terdapat tiga unsur dalam membangun kesadaran, yaitu pertama adanya konsistensi penggunaan \#JMDP pada setiap kegiatan kampanye. Kedua, strategi proaktif dapat membantu untuk menjangkau masyarakat. Ketiga, penempatan pada sesi peningkatan kesadaran dengan ALZI dinilai sudah tepat dalam meningkatkan kesadaran peserta Summer School yang dapat menjadi agen kampanye di lingkungannya masing-masing. Maka, dapat disimpulkan bahwa kampanye \#JMDP menggunakan proaktif dan reaktive strategy, penyusunan strategi kampanye sesuai dengan model Ostergaard, dan penempatan sesi peningkatan kesadaran sudah sesuai untuk membangun kesadaran akan isu demensia.
\end{abstract}

Kata-kata Kunci: Hubungan masyarakat; strategi kampanye; kesadaran; isu; komunikasi kesehatan

\section{The Alzheimer Indonesia's campaign strategy \#janganmaklumdenganpikun in building awareness of dementia issues \\ ABSTRACT}

\begin{abstract}
Alzheimer Indonesia (ALZI), a non-profit organization, created a social campaign with the theme \#JanganMaklumDenganPikun (\#JMDP) in building public awareness on the matter. The campaign carried out by ALZI aims to raise public awareness about dementia which cannot be taken lightly. Senile is no longer a common thing because it can be one of the signs or symptoms of dementia. This study discusses the campaign strategy carried out by Alzheimer Indonesia (ALZI) with the theme \#JanganMaklumDenganPikun (\#JMDP) in building awareness of the dementia issue. The research focuses on the Summer School program at the Faculty of Medicine, Atma Jaya Catholic University of Indonesia. The \#JMDP campaign is designed around the issue of lack of public awareness of dementia. In this study, the concepts used are Public Relations, Campaigns, Public Campaign Strategies (focusing on the Ostergaard campaign model), Issues, and Health Communication. The method in this study uses qualitative research with a descriptive analysis approach. Data collection techniques are carried out in two ways, namely in-depth interviews and documentation studies. The study results show that there are three elements in building awareness; namely, the first is the consistency of \#JMDP in every campaign activity. Second, proactive strategies enable easier reach to the community. Third, the placement in an awareness-raising session with ALZI was considered appropriate in increasing the awareness of Summer School participants who could become campaign agents in their respective environments. So, it can be concluded that the \#JMDP campaign uses a proactive and reactive strategy, the preparation of a campaign strategy according to the Ostergaard model, and the placement of awareness-raising sessions are appropriate to build awareness of the dementia issue.
\end{abstract}

Keywords: Public relations; campaign strategy; awareness; issue; health communication

Korespondensi: El Chris Natalia. Universitas Katolik Indonesia Atma Jaya. Jalan Jenderal Sudirman No.51 Jakarta.Email: elchris.natalia@atmajaya.ac.id. 


\section{PENDAHULUAN}

Kementerian Kesehatan Republik Indonesia menyatakan melalui www.kemkes. go.id (2019), Indonesia sedang memasuki periode aging population yang merupakan masa saat jumlah harapan hidup meningkat seiring dengan meningkatnya jumlah penduduk lansia. Berdasarkan informasi dari Kementerian Kesehatan Republik Indonesia tersebut, jumlah lansia mencapai 18 juta jiwa (7,56\%), mengalami peningkatan pada 2019 menjadi 25,9 juta jiwa $(9,7 \%)$ dan diperkirakan pada 2035 akan mencapai 48,2 juta jiwa (15,77\%). World Health Organization (WHO) menyatakan saat penduduk global bertambah usia maka jumlah orang hidup dengan demensia diperkirakan berlipat tiga sampai 2050. Direktur Jenderal WHO, Tedros Adhanom Ghebreyesus menjelaskan dalam wawancara bahwa hampir sepuluh juta orang terserang demensia setiap tahun dan enam juta diantaranya berada pada negara yang berpenghasilan rendah. Maka, seiring meningkatnya jumlah lansia ada kemungkinan meningkatnya juga tingkat penyakit degenerative (Maharani, 2017).

SurveyMETER melakukan sebuah penelitian untuk mengukur tingkat prevalensi penyakit demensia terhadap penduduk lansia yang dilakukan di Yogyakarta. Mereka menemukan bahwa jumlah prevalensi lansia umur 60 tahun atau lebih mencapai 20,1\% (Suriastini et al., 2016). Persentase umur dimulai pada umur 60 tahun ke atas sudah mencapai $7,0-9,4 \%$, sedangkan pada umur 70-79 mencapai $22,5 \%$ - 21,7\%, pada umur 80-89 mencapai 38,6\% - 49,5\% dan pada umur 90 tahun ke atas mencapai 70,4\%. Berdasarkan pada jenis kelamin dari jumlah total $20,1 \%$ maka diperoleh hasil bahwa pada laki-laki sekitar 17,9, sedangkan pada perempuan 22,0 dan berdasarkan pada tempat tinggal maka diperoleh sekitar 17,8 berada di perkotaan, sementara sekitar 23,0 di perdesaan.

Hasil yang ditampilkan pada SurveyMETER tersebut juga menunjukkan pengukuran pada tingkat pengetahuan dari dua sisi, yaitu dari sisi lansia dan pendamping. Survei tersebut berdasarkan 10 tanda dasar gejala dementia, antara lain; 1) gangguan daya ingat; 2) sulit fokus; 3) sulit melakukan kegiatan yang familier; 4) disorientasi; 5) kesulitan memahami visio spasial; 6) kesulitan berkomunikasi; 7) menaruh barang tidak pada tempatnya; 8) salah membuat keputusan; 9) menarik diri dari pergaulan; dan 10) perubahan perilaku dan kepribadian. Data tersebut menyebutkan bahwa pengetahuan mengenai gejala demensia masih sangat rendah, sekitar 4-16\% dari lansia dan pendamping yang memiliki pengetahuan akan gejala demensia (Suriastini et al., 2016).

Kampanye yang sukses memerlukan 
strategi yang tepat agar dapat diimplementasikan dengan baik pada publik yang dituju. Strategi komunikasi sebagai kampanye komunikasi terencana dilakukan oleh suatu perusahaan, organisasi nirlaba, dan terkadang oleh organisasi yang tidak terstruktur. Strategi komunikasi didasari oleh riset dan subjek dari kampanye yang dapat dievaluasi pada akhir kampanye. Dalam pelaksanaannya, strategi tersebut tidak hanya melibatkan para anggota organisasi tetapi juga orang-orang yang berada di sekitar organisasi (Smith, 2017).

Alzheimer Indonesia (ALZI) sebuah organisasi nirlaba membuat kampanye sosial dengan \#JanganMaklumDenganPikun untuk membangun kesadaran masyarakat. Tujuan dari kampanye tersebut adalah untuk meningkatkan kesadaran masyarakat akan isu demensia yang tidak bisa dianggap sebagai hal remeh. Pikun tidak lagi menjadi sesuatu hal yang biasa karena dapat menjadi salah satu tanda atau gejala dari penyakit demensia. \#JanganMaklumDenganPikun merupakan grabbers dalam pesan karena slogan tersebut dapat menarik perhatian masyarakat dan diimplementasikan ke dalam beberapa program.

Salah satu contohnya dapat dilihat pada kitabisa.com, ALZI membuat kampanye untuk donasi program pelatihan dan penguatan bagi para caregivers, antara lain melakukan kegiatan olah tubuh bagi para lansia dengan tujuan untuk mengurangi resiko terkena demensia, seperti tari poco-poco, workshop, dan seminar.

Dalam menjalankan programnya, ALZI memiliki dukungan dari berbagai macam pihak, seperti dari psikolog, neurolog, spesialis komunikasi kesehatan, pengacara, geriatric psychiatrist, dan lainnya. ALZI juga bekerja sama dengan perguruan tinggi, seperti Universitas Katolik Indonesia Atma Jaya (Unika Atma Jaya) dengan adanya ATZI Center. Bentuk kerja sama yang dilakukan adalah dengan menyiapkan wadah untuk mengedukasi dan mensosialisasikan isu demensia terhadap masyarakat. Bertempat di Universitas Katolik Indonesia Atma Jaya Semanggi, Gedung K2, Lantai 3, Ruangan 14 (K314), ATZI Center menyediakan akses informasi terhadap para ODD, keluarga ODD, dan caregivers. Selain menjadi wadah untuk edukasi, ATZI Center juga menjadi tempat untuk penelitian mengenai isu demensia di Indonesia (www.alzi.or.id).

Pada penelitian ini terdapat beberapa referensi yang diambil dari penelitian terdahulu. Penelitian pertama berjudul "Strategi Kampanye Breast Cancer Awareness Month" (Chandra, 2014). Pendekatan penelitian yang digunakan adalah kualitatif dengan metode studi kasus. Hasil dari penelitian tersebut adalah peneliti menemukan dalam kampanye BCAM 2012, komunitas RRS mengalami perluasan target audiens yang pada awalnya 
berupa wadah sharing yang ditujukan hanya bagi para survivor dari kanker payudara tetapi juga kepada para kaum perempuan dan secara khusus remaja putri. Terdapat beberapa pesan utama yang ingin disampaikan RRS, yaitu: 1) Seberapa umum kanker payudara; 2) Pengetahuan umum mengenai kanker payudara; 3) Tanda dan gejala kanker payudara; 4) Faktorfaktor dan resiko yang ada; 5) Deteksi dini dan screening. Dalam melakukan kampanye, RRS menggunakan strategi dengan membuat health education dalam bentuk talkshow pada media, seperti KompasTV, Radio Kosmonita, She, dan lain-lain. Strategi tersebut tidak hanya dilakukan kepada para media, tetapi juga kepada instansi perguruan tinggi, seperti di Universitas Airlangga dengan melakukan sosialisasi mengenai kanker payudara.

Penelitian kedua berjudul "Strategi Komunikasi Duta HIV/AIDS dalam Kampanye HIV/AIDS di Kalangan Transgender pada Ikatan Waria Malang” (Lasari et al., 2015). Metode penelitian menggunakan deskriptif kualitatif dengan wawancara mendalam terhadap beberapa informan. Tujuan dari penelitian ini adalah untuk mengukur strategi komunikasi duta HIV/AIDS dalam kampanye terhadap kalangan transgender untuk mengkomunikasikan mengenai HIV/AIDS kepada para kalangan transgender yang rentan terhadap penyakit tersebut. Hasil pada penelitian ini menunjukkan bahwa strategi komunikasi yang digunakan oleh Duta HIV/AIDS dalam melakukan kampanye adalah menggunakan komunikasi antarpribadi antara fasilitator dengan komunikan juga menggunakan event edutainment sebagai wadah kegiatan. Namun, terdapat hambatan dari tingkat pendidikan komunikan yang rendah sehingga dalam melakukan penyampaian informasi seputar medis komunikator tidak dapat secara spesifik memberitahu informasi tersebut karena tidak sesuai dengan kemampuan komunikan dalam mencerna informasi. Faktor credibility yang terbangun dalam pola komunikasi antara komunikator dengan komunikan menjadi kunci kesuksesan dalam melakukan komunikasi dari kampanye HIV/AIDS.

Berdasarkan dua penelitian terdahulu tersebut, terdapat kesamaan dalam tema penelitian, yaitu analisis strategi kampanye dengan fokus bidang komunikasi kesehatan. Kesamaan lainnya adalah tema kampanye yang diambil adalah kampanye sosial. Tujuan dari kedua kampanye dari penelitian sebelumnya adalah untuk mengubah perilaku masyarakat agar menjadi lebih baik terhadap masingmasing isu sosial yang dihadapi. Perbedaan penelitian terdahulu dengan penelitian ini adalah pada penelitian pertama, mengkomunikasikan mengenai kanker payudara terhadap para survivor, remaja putri, dan wanita yang tidak 
menderita kanker payudara agar memiliki kesadaran akan potensi penyakit tersebut. Penelitian kedua mengkomunikasikan isu mengenai HIV/AIDS terhadap kalangan transgender dalam ikatan waria malang melalui program Duta HIV/AIDS. Masalah yang ingin diteliti adalah mengenai tingkat pemahaman akan penyakit HIV/AIDS oleh para transgender yang rentan terhadap penyakit tersebut.

Tujuan dari kampanye terbagi menjadi dua, yaitu tujuan (aims) dan objektivitas (objective). Tujuan merupakan sebuah pernyataan umum yang komunikator ingin sampaikan kepada publik. Pernyataan ini tidak memiliki aspek spesifik yang dapat diukur. Sementara, objektivitas merupakan turunan dari tujuan dan bersifat lebih spesifik serta terukur (Gregory, 2000). Semua aktivitas hubungan masyarakat harus mencerminkan tujuan dan sasaran bisnis, baik untuk klien maupun perusahaan. Tujuan dan sasaran harus didefinisikan dalam kegiatan guna mengukur dengan jelas hasil yang akan dipengaruhi oleh hubungan masyarakat dan komunikasi korporasi (Michaelson, Wright, \& Stacks, 2012). Kegiatan-kegiatan ini dapat berupa berbagai hal, mulai dari rilis media hingga opini, kit media hingga video rilis baru (VNR), blog dan tweet, dan sebagainya.

Strategi kampanye \#JMDP yang membahas tentang kesadaran akan isu demensia ini berada pada konteks komunikasi kesehatan. Komunikasi kesehatan adalah studi yang meliputi strategi komunikasi dengan tujuan untuk memberikan informasi serta mempengaruhi pengetahuan, perilaku, tindakan individu dan komunitas terkait isu kesehatan. Komunikasi kesehatan dapat diaplikasikan pada dua hal, yaitu health-promotion dan disease prevention. Beberapa tujuan dari komunikasi kesehatan sebagai berikut: 1) untuk mendukung kehidupan sehat, 2) membangun kesadaran akan kesehatan, 3) mengubah perilaku individu, dan 4) memotivasi individu untuk mengadaptasi perilaku yang disarankan (Thomas, 2006). Komunikasi kesehatan adalah kajian yang berfokus pada peranan teori komunikasi yang dapat digunakan dalam penelitian dan praktik yang berhubungan dengan promosi dan pemeliharaan kesehatan. Komunikasi kesehatan juga adalah proses pengembangan atau pembagian pesan kesehatan kepada khalayak tertentu dengan tujuan untuk mempengaruhi pengetahuan, sikap, dan keyakinan mereka tentang pilihan perilaku hidup sehat (Komariah, Perbawasari, Nugraha, \& Budiana, 2013).

Berdasarkan pemaparan tersebut, maka penelitian ini akan menganalisis mengenai strategi kampanye yang dilakukan oleh Alzheimer Indonesia (ALZI) dalam meningkatkan kesadaran masyarakat akan pentingnya gejala demensia. Masyarakat dalam hal ini adalah peserta program Summer School 
FK UAJ. Peneliti tertarik melakukan penelitian ini karena ALZI sebagai organisasi non-profit memiliki peranan penting dalam melakukan edukasi mengenai penyakit demensia kepada masyarakat, agar memiliki pemahaman sehingga dapat melakukan pencegahan ataupun penanganan yang sesuai.

Penelitian ini berfokus pada strategi kampanye dengan tahapan menyusun kampanye melalui beberapa tahap yaitu 1) Research, dengan penemuan fakta mengenai isu penderita demensia; 2) Strategy, dengan melakukan rancangan program untuk mengedukasi dan membangun kesadaran masyarakat akan pentingnya gejala awal demensia; 3) Tactics, implementasi dari hasil rancangan dalam bentuk program edukasi bagi masyarakat; dan 4) Evalution, hasil evaluasi dari program yang sudah dijalankan (Smith, 2014).

Selain itu, penelitian ini juga akan dianalisis dengan menggunakan model kampanye Ostergaard berdasarkan Klingemann. Model ini pertama kali dirumuskan oleh Leon Ostergaard yang merupakan seorang praktisi kampanye sosial. Pada model ini terdapat dua tahap. Pertama, tahap pre-campaign merupakan tahap pada saat penyusun kampanye memetakan masalah (problems) yang sedang dihadapi. Setiap strategi kampanye (campaign) berasal dari permasalahan yang ingin diselesaikan dengan mengidentifikasi melalui cause and effect relationship. Pengumpulan faktafakta yang ada terkait dengan masalah akan menghasilkan hubungan sebab-akibat jika permasalahan tidak selesaikan. Tahap kedua adalah campaign management, dimulai dari perancangan kampanye, implementasi strategi, dan evaluasi (Venus, 2009).

Dalam tahap perancangan, dilakukan riset terhadap publik yang dituju agar dapat menentukan aktor kampanye, saluran komunikasi, merumuskan pesan, dan teknis pelaksanaan kampanye. Sementara dalam implementasi strategi adalah tahap saat organisasi melakukan pengelolaan pada isi kampanye (campaign content) agar mudah untuk dimengerti oleh publik yang dituju. Peningkatan pada pengetahuan dan keterampilan akan memberikan perubahan pada sikap dari khalayak terhadap sesuatu. Evaluasi merupakan tahap yang paling penting dalam manajamen kampanye. Proses evaluasi adalah pada saat pasca kampanye dengan tujuan untuk mengurangi masalah atau isu (reduced problems) yang diangkat oleh organisasi (Venus, 2009). Berdasarkan pemaparan ini, maka peneliti melakukan penelitian dengan judul "Strategi Kampanye Alzheimer Indonesia \#JanganMaklumDenganPikun dalam Membangun Kesadaran akan Isu Demensia”. Penelitian ini berfokus pada strategi kampanye yang digunakan oleh ALZI 
dengan tagar \#JanganMaklumDenganPikun pada satu sesi mengenai awareness raising (peningkatan kesadaran) dari program Summer School Fakultas Kedokteran Unika Atma Jaya (FK UAJ). Tujuan penelitian ini adalah untuk mengetahui strategi kampanye dari Alzheimer Indonesia (ALZI) dalam membangun kesadaran masyarakat mengenai isu demensia pada peserta program Summer School FK UAJ.

\section{METODE PENELITIAN}

Pada penelitian ini, pendekatan penelitian yang digunakan adalah kualitatif deskriptif. Penelitian kualitatif melibatkan eksplorasi induktif data untuk mengidentifikasi tema, pola, atau konsep yang berulang dan kemudian menggambarkan serta menafsirkan kategori tersebut. Selain itu, penelitian deskriptif adalah untuk menggambarkan sebuah fenomena dan karakteristik dari fenomena tersebut (Nassaji, 2015). Secara desain, peneliti kualitatif akan mendapatkan lebih banyak informasi tentang suatu fenomena. Dalam hal ini, peneliti menyadari bahwa hasilnya tidak akan dapat digeneralisasikan ke populasi karena sangat sedikit peserta berpartisipasi dalam studi yang menawarkan begitu banyak kedalaman detail adalah sebagai kelemahan utama (Jackson, Drummond, \& Camara, 2007). Pemahaman lainnya mengenai penelitian deskriptif adalah penelitian deskriptif juga ditujukan untuk mengeksplorasi dan mengklarifikasi tentang suatu fenomena atau realita sosial (Mulyadi, 2013).

Objek penelitian ini adalah strategi kampanye ALZI dalam meningkatkan kesadaran akan isu demensia. Subjek penelitiannya adalah pihak pengurus ALZI, panitia, pembicara, dan peserta Summer School Fakultas Kedokteran Unika Atma Jaya. Lebih detail, subjek penelitiannya, antara lain a) Executive Director Alzheimer Indonesia (ALZI), PT. Berdasarkan informasi yang disampaikan oleh PT, sebagai Executive Director, PT langsung terlibat dalam menentukan strategi kampanye yang dijalankan; b) dr. T, sebagai koordinator dari program Summer School oleh FK UAJ; c) dr. O, sebagai koordinator dari program Summer School dan juga neurologist; d) GV, mahasiswi FK UAJ yang mengikuti rangkaian program summer school; e) AV, mahasiswa FK UAJ yang mengikuti rangkaian program summer school; dan f) AH, dosen Program Studi IImu Komunikasi, Unika Atma Jaya.

Penelitian ini menggunakan teknik pengumpulan pada data primer dan sekunder Data primer dilakukan melalui teknik wawancara. Wawancara dapat dengan mudah digambarkan sebagai bentuk konsultasi di mana penelitiberusaha untuk mengetahui lebih banyak tentang suatu masalah seperti yang dikemukakan 
oleh individu yang ditanyakan. Wawancara dapat dipahami sebagai proses interaktif di mana seseorang mengajukan pertanyaan untuk mencari informasi tertentu (Adhabi \& Anozie, 2017). Pada penelitian ini peneliti menggunakan wawancara tidak terstruktur yang memiliki tujuan untuk memperoleh bentuk-bentuk tertentu dari informasi responden. Urutan dari pertanyaan akan disesuaikan dengan ciri-ciri setiap responden. Wawancara tidak terstruktur memiliki sifat tidak kaku karena setiap susunan kata dan pertanyaan dapat diubah saat proses wawancara sedang berlangsung (Mulyana, 2013). Selain itu, peneliti juga menggunakan pertanyaan terbuka atau tidak terstuktur, yaitu pertanyaan yang dibuat dan jawaban yang diperoleh bisa berbagai macam jawaban. Pertanyaan terbuka lebih sering digunakan dalam panduan wawancara karena alternatif dalam menjawab tidak dibatasi sehingga dapat menggali informasi lebih dalam.

Data sekunder pada penelitian ini dilakukan melalui studi dokumentasi. Studi dokumen merupakan sarana pembantu peneliti dalam mengumpulkan data atau informasi dengan cara membaca surat-surat, pengumuman, pernyataan tertulis kebijakan tertentu dan bahan-bahan tulisan lainnya. Pada studi atau kajian dokumen, peneliti dapat mengenal budaya dan nilai-nilai yang dianut oleh objek yang diteliti melalui dokumentasi yang ada (Nilamsari, 2014). Pada penelitian ini, dokumentasi dipelajari dari datadata dari website resmi Alzheimer Indonesia, foto dokumentasi kegiatan Summer School FK UAJ, dan materi seminar sesi peningkatan kesadaran dari Alzheimer Indonesia untuk acara Summer School FK UAJ.

Peneliti melakukan pengecekan keabsahan data melalui triangulasi. Triangulasi dapat membantu memastikan bahwa bias mendasar yang timbul dari penggunaan metode tunggal atau pengamat tunggal dapat diatasi. Triangulasi juga dapat memperkaya penelitian karena menawarkan berbagai kumpulan data untuk menjelaskan berbagai aspek fenomena yang menarik (Noble \& Heale, 2019). Triangulasi digunakan dalam studi yang menggunakan wawancara untuk tujuan yang berbeda tergantung pada kerangka interpretatif peneliti (Natow, 2019). Pada penelitian ini, peneliti menggunakan metode triangulasi sumber. Data yang diperoleh dari hasil wawancara akan dibandingkan melalui beberapa sumber terkait. Peneliti menguji kredibilitas data dari berbagai sumber yang terkait, seperti hasil wawancara dari pengurus ALZI sebagai campaign-maker dari kampanye \#JMDP, hasil testimoni dari panitia program Summer School FK UAJ mengenai paparan kampanye, dari peserta dan pembicara yang berpartisipasi dalam acara tersebut. Hasil wawancara lainnya adalah dari pandangan panitia Summer School sebagai 
penyelenggara acara dalam menilai seberapa penting kampanye tersebut. Setelah melakukan triangulasi data, selanjutnya data akan dideskripsikan, dikategorikan, dan diverifikasi untuk mencapai kesimpulan.

\section{HASIL \& PEMBAHASAN}

ALZI diharapkan dapat meningkatkan kesadaran dalam masyarakat akan pentingnya memahami gejala pikun. Strategi Kampanye \#JMDP merupakan upaya dari ALZI untuk meningkatkan kesadaran akan pentingya melakukan pengecekan ke dokter ketika terdapat orang tua dalam keluarga yang sudah mengalami gejala pikun.

"Seringkali kita suka enggak sadar, perkara itu orang awam, maupun tenaga medis sekalipun, tentang perilaku kakek nenek yang mulai turun kognitifnya, bahkan menganggap itu hal yang lumrah." (wawancara GV).

Orang awam dan tenaga medis belum tentu memiliki pengetahuan akan kondisi dari geriatric (lansia) yang mengalami demensia. Kesenjangan yang luas terjadi karena banyak pemahaman masyarakat akan penurunan kognitif (pikun) merupakan hal lumrah dalam proses penuaan.

Dalam melakukan strategi kampanye, ALZI menjalankan salah satu fungsi PR, yaitu dengan menyebarkan informasi kepada publiknya dengan menjadi jembatan untuk para anak muda yang merupakan bagian dari keluarga. Dampak yang dihasilkan dengan kampanye \#JMDP menjadi jembatan adalah adanya exposure terhadap keluarga. Pada salah satu dampak yang dihasilkan dari komunikasi kesehatan adalah pada bagian lingkungan sosial dan individu.

"Gak pasti sih mungkin mau dari semua bidang atau populasinya apapun mungkin lebih ke edukasi ke keluarganya." (wawancara AV).

Fungsi kampanye adalah untuk melakukan edukasi terhadap anak muda sehingga hasil edukasi dapat dibawa ke dalam unit terkecil dalam lingkungan sosial yaitu keluarga. Dampak pada individu juga dirasakan oleh GV. GV menyatakan bahwa dampak dari strategi kampanye yang dihasilkan pada individu adalah dengan terbentuknya perilaku untuk mengajak atau mempromosikan kegiatan kampanye kepada orang lain.

"Menurutku biar apa yang udah kita pelajarin enggak di-keep sendiri, tapi bisa juga untuk ajak orang lain untuk lebih care." (wawancara GV).

Kampanye \#JMDP termasuk proactive strategy karena ALZI selaku organisasi mengambil langkah awal untuk berkomunikasi dengan publiknya. PT menyatakan bahwa dalam melakukan strategi kampanye, ALZI mempromosikan mengenai kesadaran akan pentingnya mengenal pikun sebagai gejala awal dari demensia. PT juga menjelaskan 


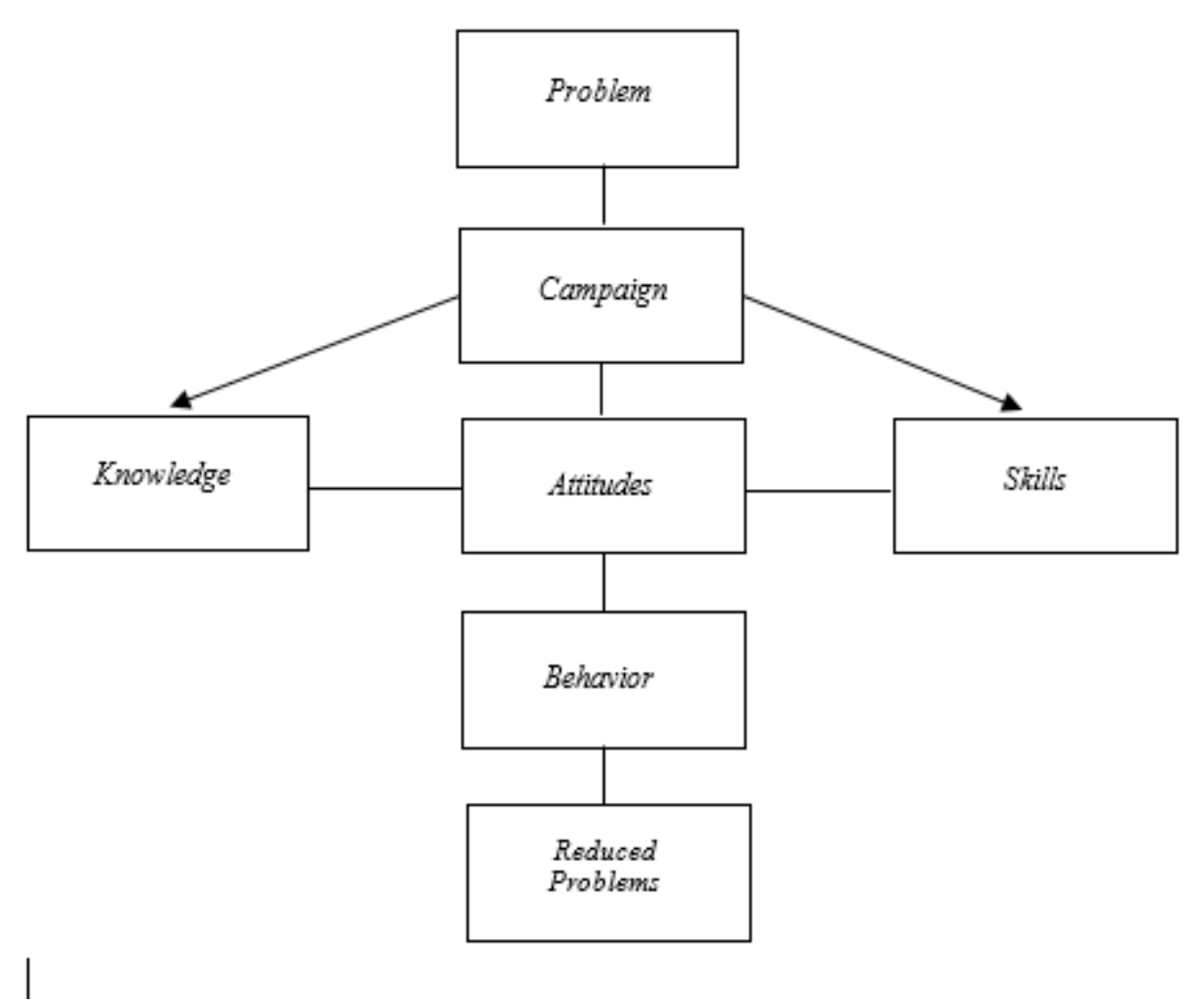

Sumber: Venus, 2009

\section{Gambar 1 Model Ostergaard}

bahwa dalam menyusun strategi kampanye \#JMDP ini mengambil acuan dari strategi kampanye Yayasan Kanker Indonesia melalui tema kampanye "Breast Cancer Awareness" dengan implementasi kegiatan berupa memakai pita pink pada bulan Oktober. Kampanye dari Yayasan Kanker Indonesia ini dinilai berhasil dalam meningkatkan kesadaran akan bahayanya kanker payudara. AV, melalui wawancara menyatakan bahwa pada prinsipnya prognosis yang lebih baik adalah treatment lebih dini lebih baik. Prognosis adalah seperti perjalanan dan kualitasnya menjadi semakin baik. Dengan adanya kampanye ini akan memicu masyarakat buat lebih sadar.
Pernyataan AV mendukung implementasi strategi yang dirancang oleh ALZI dengan bentuk proactive strategy dengan dampak yang dapat dihasilkan berupa prognosis yang lebih baik sehingga dapat dilakukan perawatan lebih awal kepada para ODD. Namun pandangan lain diberikan oleh GV dalam hasil wawancara yang menyatakan bahwa melalui strategi kampanye \#JMDP termasuk dalam reactive strategy dengan penjelasan bahwa kampanye digunakan sebagai bentuk perlawanan terhadap stigma negatif yang sudah ada dalam lingkungan masyarakat. Berdasarkan dari ketiga hasil wawancara tersebut, jenis strategi kampanye \#JMDP bergantung pada tujuan dari kegunaan 
kampanye. Terdapat dua tujuan berdasarkan kegunaan, yang pertama dalam bentuk proactive maka strategi kampanye \#JMDP digunakan sebagai tindakan promosi kesadaran dan prognosis yang lebih baik, sementara dalam bentuk reactive maka strategi ini digunakan dalam mengurangi stigma negatif yang sudah terbentuk dengan memberikan pemahaman baru.

Dasar dari penyusunan kampanye sosial model Ostergaard adalah isu atau permasalahan yang sedang berlangsung dalam lingkungan publik. Pada kaitan penelitian maka isu yang muncul adalah mengenai kesadaran masyarakat luas akan pentingnya memahami penyakit demensia. Salah satu tanda awal dari penyakit demensia adalah dengan adanya penurunan kognitif yang terjadi pada geriatric (lansia), yang secara awam masyarakat luas ketahui sebagai pikun. Hal ini didukung oleh hasil wawancara dengan dr. O:

"Tentunya penting ya karna kalau tidak tahu dan kata-katanya "Jangan Maklum Dengan Pikun" memang diperuntukkan untuk mengedukasi masyarakat kalau pikun itu bukan bagian yang normal dari penuaan dan memang kalau masyarakat belum tahu soal ini maka tidak ada rasa urgensi bahwa ini adalah sesuatu yang harus dihadapi dan ditangani." (wawancara dr. O).

Berdasarkan pada penjelasan isu, hal ini dianggap penting untuk dikampanyekan karena masih terdapat pemahaman atau stigma yang salah terhadap kepikunan sebagai salah satu yang lumrah dalam proses penuaan. Pemahaman yang salah menjadi faktor utama semakin luas atau jauh kesenjangan yang dihasilkan antara aktivitas organisasi dengan harapan publik. "Jadi \#JMDP itu sendiri karena stigma masyarakat masih menganggap pikun itu sebagai sesuatu yang normal, nah dari situ kita belajar bahwa ini penting. Prosesnya kan tidak seperti itu, banyak stigma karna udah tua lah maklum jadi pikun, kita ingin mematahkan stigma tersebut. Banyak orang tua yang masih menganggap kalau mereka itu pikun padahal bukan.” (wawancara PT).

Pernyataan PT tersebut juga diperkuat dengan pernyataan dari hasil wawancara dengan AH melalui penjelasan dari hasil wawancara sebagai berikut:

"Karna dia (demensia) sudah penyakit langka bahkan penyembuhan secara medis belum ditemukan, itulah kenapa perlunya adanya kampanye, agar publik itu tahu, aware, dan paham mengenai si penyakit demensia atau Alzheimer itu. Karna masih banyak stigma yang terbentuk di masyarakat mengenai penyakit ini, seperti di daerah kalau penyakit ini penyakit kutukan, penyakit apalah ditenun orang, ni orang yang tadinya sehat walafiat tibatiba enggak tahu jalan pulang, seolah-olah diguna-guna gitu kan." (wawancara AH).

Hasil wawancara tersebut menyatakan bahwa terdapat pengaruh mitos yang membentuk stigma negatif terhadap isu menjadi semakin kuat. Berdasarkan hasil wawancara ini, maka unsur pertama yang membentuk adanya kesenjangan antara aktivitas organisasi dengan harapan publik dengan masyarakat luas sebagai publik adalah stigma yang ada dalam lingkungan 
yaitu stigma akan pikun yang menjadi suatu hal yang lumrah sehingga menjadi pembatas untuk meningkatnya kesadaran masyarakat akan pentingya isu demensia.

"Dalam usaha mengatasi penyakit yang tidak bisa disembuhkan tentunya kita menekankan pada deteksi dini, dalam artian kita mendapatkan bisa di awal sehingga disaat kita melakukan tindakantindakan untuk memperlambat atau menghambat perjalanan penyakitnya. Oleh karena itu, tentunya ditekankan ke awam bahwa ada loh penuaan yang sifatnya tidak normal salah satunya ya kepikunan itu tadi. Jadi yang kita harapkan pasien bisa dibawa kerumah sakit pada stadium awal sehingga dengan demikian dapat dilakukan intervensi yang lebih cepat dan tentunya harapan pemulihannya lebih baik jika dibandingkan dengan perawatan yang dilakukan pada stadium lanjut, seperti demikian." (wawancara dr. O).

Berdasarkan hasil penjelasan di atas, maka unsur kedua dapat dikatakan bahwa harapan publik yang merupakan tenaga medis adalah untuk melakukan deteksi dini kepada para ODD (Orang Dengan Demensia). Kesenjangan yang luas berdampak pada kurangnya deteksi dini, dengan banyak masyarakat yang masih belum memeriksakan diri kepada dokter terkait.

Kementerian Kesehatan Republik Indonesia (www.kemkes.go.id, 2019) menyatakan pada 2010 jumlah lansia mencapai 18 juta jiwa (7,56\%) dan mengalami peningkatan pada 2019 menjadi 25,9 juta jiwa $(9,7 \%)$ dan diperkirakan pada 2035 akan mencapai 48,2 juta jiwa $(15,77 \%)$. Berdasarkan data tersebut, maka ini menjadikan isu demensia sebagai isu yang penting untuk ditangani.

"Karena semakin ke sini usia harapan hidup meningkat dan banyak populasi orang tua maka semakin meningkat potensi penyakit degenerative makin tinggi dan perkembangan teknologi serta dunia digital dan karna itu tadi semakin banyak banyak orang tua." (wawancara PT).

Hasil wawancara menyatakan bahwa unsur ketiga yang menjadikan isu ini penting adalah peningkatan jumlah harapan hidup dari lansia akan beriringan dengan peningkatan penyakit degeneratif. PT berpendapat bahwa dengan adanya peningkatan ini akan membuat isu menjadi sangat penting untuk dapat diselesaikan.

Kampanye ini dibuat dengan tujuan untuk meningkatkan kesadaran masyarakat sekaligus meningkat juga support system, yaitu para enablers yang mendukung program kampanye. Penetapan tujuan adalah untuk meningkatkan kesadaran dan didasari oleh kebutuhan akan support system yang lebih memadai. Dalam menetapkan tujuan dari kampanye, berdasarkan hasil wawancara, ALZI berfokus untuk melakukan analisis publik dengan jenis publik, yaitu enablers, publik yang memiliki kemampun untuk mendukung kegiatan organisasi. Maka, dengan adanya banyak enablers yang tergabung akan terdapat banyak kesempatan bagi organisasi untuk memperkecil kesenjangan. Semakin banyak orang yang sadar dan terlibat, maka akan semakin banyak juga 
support system-nya.

Para enablers yang dituju oleh Alzheimer Indonesia berasal dari dua kalangan, yaitu nonmedis dan medis. Hal ini dijelaskan dalam hasil wawancara dengan AV bahwa kemasan pesan kampanye yang bersifat proactive membuat bagi kalangan non-medis untuk menjadi lebih sadar terhadap isu yang sedang terjadi, ditandai dengan adanya peningkatan pengetahuan dan perubahan sikap. Bagi pihak medis adalah untuk memicu adanya interdisiplin antar bidang medis dalam menangani kasus penyakit demensia.

Tahap selanjutnya dalam menyusun kampanye adalah dengan menggunakan kemasan pesan yang menarik perhatian. Kemasan pesan bersifat edukatif dengan subtujuanuntukmengubahpolapikirmasyarakat dengan tagar \#JanganMaklumDenganPikun. PT menjelaskan bahwa terdapat tiga pesan utama sebagai berikut: 1) untuk mengubah pola pikir bahwa pikun sebagai hal normal tidak dapat lagi digunakan, 2) mengajak masyarakat ketika sudah mengalami gejala pikun sesegera mungkin untuk memeriksakan diri ke dokter, dan 3) untuk tetap menjadi sigap dalam mencari informasi terkait bagaimana perjalanan penyakit demensia.

Penggunaan grabbers dalam konten pesan \#JMDP juga menjadi salah satu daya tarik untuk meningkatkan kesadaran masyarakat. Hal ini sejalan dengan pemaparan dari dr. T.
"Kalau untuk di masyarakat, dengan satu campaign, dengan kata-kata yang catchy pasti dapat menarik perhatian masyarakat sehingga pertama masyarakat penasaran dulu nih eh apa nih, sesuatu yang mereka pikir normal kok dibilang jangan maklum." (wawancara dr. T).

\section{Slogan \#JMDP (Jangan Maklum Dengan} Pikun) dinilai dapat membuat masyarakat tertarik. Ketertarikan muncul karena adanya rasa penasaran akan sesuatu yang pada awamnya dianggap normal namun pada tingkat medis merupakan sesuatu yang tidak normal. Penjelasan ini diperkuat dengan pendapat dr. O dari hasil wawancara dengan menjelaskan bahwa kata "pikun" sering diasosiasikan sebagai kondisi normal yang terjadi pada lansia. \#JMDP ini membuat masyarakat menjadi tertarik atau timbul rasa penasaran karena sesuatu yang dianggap normal tidak lagi dianggap sebagai hal yang normal. Menurut dr. O, \#JMDP memiliki dampak untuk menimbulkan ketertarikan yang nantinya menjadi deteksi dini dengan masyarakat melakukan pengecekan kepada dokter atau tenaga medis

Penggunaan grabbers juga menentukan positioning yang dilakukan oleh ALZI terhadap isu demensia. Positioning yang dibentuk adalah membuat ALZI sebagai organisasi NGO yang memiliki kepedulian terhadap isu demensia, yang awalnya dianggap sebagai suatu hal lumrah dapat menjadi suatu hal yang penting. 
AV menjelaskan dari penggunaan \#JMDP akan membuat publik untuk mempertanyakan kembali mengenai stigma yang sudah terbentuk.

Peran grabbers mampu memperkuat positioning ALZI sebagai organisasi yang memiliki kepedulian terhadap isu demensia meskipun belum terlalu terpapar. Kedua pandangan menyatakan bahwa penggunaan grabbers \#JMDP dengan membuat kontrakdisi terhadap sesuatu yang lumrah di masyarakat, mampu memperkuat positioning ALZI sebagai non-government organization yang memiliki kepedulian tinggi terhadap isu demensia.

Tahap ketiga adalah mengenai saluran komunikasi yang disesuaikan dengan target audiens, seperti penggunaan medium komunikasi yang disesuaikan dengan target audiens yang dituju. Terbagi menjadi dua, yaitu khalayak umum dengan melalui media sosial, seperti Instagram dan Facebook terkait kegiatan organisasi, dan khalayak internal organisasi dengan menggunakan medium WhatsApp Messenger untuk melakukan broadcast message mengenai informasi terkait kegiatan. Selain menggunakan medium komunikasi, kampanye juga dilakukan secara offline melalui beberapa bentuk kegiatan, salah satunya adalah seminar, seperti yang dilakukan pada program Summer School.

Tahap keempat adalah mengenai tata pelaksanaan kampanye melalui program
Summer School. Konsistensi penggunaan tagar \#JMDP membuat kampanye semakin efektif dilakukan. Misalnya penggunaan kaos yang bertuliskan \#JMDP membuat kekuatan pesan semakin kuat. Sesi experience yang dilakukan oleh PT pada Summer School dinilai sebagai tindakan tepat untuk memperkuat pesan kampanye kepada khalayak umum, seperti yang dijelaskan dalam hasil wawancara dengan dr. T: "Sedangkan yang dari ka PT, memang tentang \#JMDP raising awareness in Indonesia, itu sebetulnya diberikan dalam format kuliah namun kita memberikan kebebasan kepada pembicara, namun pada waktu itu pembicara mengajak peserta untuk poco-poco, yang merupakan salah kegiatan risk reduction yang diselenggarakan oleh ALZI." (wawancara dr. T).

Melalui tata pelaksanaan, kampanye dinilai mampu membuat target audiens memahami maksud pesan dari \#JMDP, seperti pada penjelasan hasil wawancara dengan panitia penyelenggara program summer school.

Berdasarkan model Ostergaard, strategi kampanye akan berdampak pada adanya peningkatan dalam bersikapyang terbagi atas dua aspek, yaitu peningkatan dari sisi pengetahuan (knowledge) dan keterampilan (skill) yang nantinya berujung pada adanya perubahan sikap (behaviour). Pada hasil wawancara dengan PT, PT memberikan penjelasan bahwa dalam merespon kampanye \#JMDP terdapat dua kelompok yang terbentuk, yaitu pertama kelompok yang memiliki penerimaan positif 
terhadap kampanye yang dijalankan.

"Jadi sebenernya setelah menerima informasi ada dua kelompok, yang pertama adalah kelompok orang yang lebih ke "oh ternyata pikun itu enggak normal" terus informasinya apa, terus kalau saya menemukan ODD apa yang harus saya lakukan, jadi dia penerimaannya lebih positif." (wawancara PT).

Kelompok yang menerima dengan positif memiliki peningkatan dari segi pengetahuan (knowledge) sehingga membangun suatu curiosity akan pentingnya isu demensia. Namun, terdapat kelompok kedua yang memiliki respon berbeda. Pada hasil wawancara dengan PT menjelaskan kelompok kedua sebagai berikut:

"Namun ada beberapa kelompok juga yang penerimaannya lebih ke rasa takut, yaa fear itu ada, kayak "wah nanti di usia saya yang sekarang kalau saya enggak jaga makan berarti saya bisa kena demensia dong" atau enggak saya akhir-akhir ini udah mulai lupa berarti saya udah demensia dong." (wawancara PT).

Respon dari kelompok kedua adalah dengan rasa khawatir dan takut terhadap isu demensia. PT dalam hasil wawancara berpendapat bahwa kedua kelompok ini muncul karena adanya perbedaan dalam pola pikir dan pandangan terhadap isu demensia. Pandangan lain diberikan oleh $\mathrm{AH}$, mendukung penjelasan PT mengenai respon positif yang dapat dihasilkan dengan adanya peningkatan dalam pengetahuan akan isu demensia.

"Kalau ada di keluarga kita yang seperti itu kita tahu untuk menghadapinya dan mendampinginya, kan banyak contoh- contoh menarik yang sering diangkat oleh ALZI itu. Yang ada hmmm ibunya yang kena demensia, terus dia masak jadi enggak tahu takaran bumbunya, jadi tawar, jadi segala macam jadi keasinan, akhirnya kalo pendampingnya tidak tahu cara mendampingi yang baik akan berantem kan. Karna yang sakti demensia itu kan (ODD) enggak merasa sakit, merasa normal aja. Jadi begitu dia melakukan aktivitas masak itu dan hasilnya tidak normal gitu kan dalam tanda kutip, kan diprotes, akhirnya jadi keributan di rumah itu." (wawancara $\mathrm{AH})$.

Berdasarkan penjelasan di atas, maka terdapat perubahan sikap (behaviour) setelah mengalami peningkatan dari segi pengetahuan (knowledge). Analogi yang diberikan dalam wawancara oleh $\mathrm{AH}$ menggambarkan perubahan sikap dalam lingkungan keluarga, dengan perubahan sikap anak yang mengerti dengan kesalahan yang dibuat oleh orang tuanya dalam memasak dipicu karena faktor penyakit demensia, sehingga tidak menimbulkan konflik dalam keluarga. Sebaliknya, terdapat juga dampak negatif karena kurangnya pengetahuan akan berdampak pada sikap negatif terhadap ODD.

"Itu lebih ke kan selama ini kan budaya Indonesia, kalo ortu udah marah dan menurut mereka udah enggak jelas jadinya yaa yaudahlah didengerin kayak ni org bentar lagi (mati)." (wawancara AV).

Pernyataan tersebut menunjukkan bahwa stigma negatif yang terbentuk membuat sikap terhadap ODD menjadi negatif. Dampak negatif 
ini akan berkaitan dengan kualitas hidup ODD, seperti yang dijelaskan AV bahwa para ODD memiliki kebutuhan untuk diperlakukan secara baik oleh pihak keluarga dengan cara menjaga rasa hormat terhadap orang tua yang terkena demensia. Maka diperlukan peningkatan dari segi pengetahuan dan keahlian dalam menangani ODD sebagai solusi. Menurut AH, jika orang tua dari seorang anak terkena demensia, maka anaknya tahu cara mendampingi yang benar. Konflik tidak akan terjadi jika anaknya tersebut paham dan tahu cara mendampingi. Melalui kampanye \#JMDP dapat terjadi perubahan sikap karena informasi yang diberikan dapat meningkatkan pengetahuan dan cara untuk merawat atau berinteraksi dengan para ODD sehingga mampu mengurangi konflik yang terjadi.

Pada tahap selanjutnya setelah adanya perubahan sikap yang dihasilkan dari segi pengetahuan dan keahlian, maka terdapat pengurangan masalah dari isu yang sedang dikampanyekan. Dalam hal ini secara khusus adalah mengenai masalah dalam kesadaran.

"Mungkin mengurangi permasalahan sih masih awal untuk dikatakan mengurangi permasalahan, tapi yang bisa dikatakan impact-nya adalah semakin banyak orang yang mengerti, semakin banyak support system yang muncul, semakin banyak ehmm komunitas-komunitas yang peduli terhadap isu ini. Kalau untuk mengurangi permasalahan sebetulnya ketika ada, permasalahan itu kan akan selalu ada, misalnya satu masalah selesai maka muncul lagi masalah lain, mungkin dari segi awareness kita sangat berhasil dengan JMDP jadi makin banyak orang yang tahu, makin banyak support system, pemerintah juga makin aware terhadap isu ini.. dan memang kita bergerak di komunitas, grassroot, dari yang paling bawah, dan mungkin itu impact yang bisa sampai saat ini dirasakan dari kampanye \#JMDP ini." (wawancara PT).

Pernyataan tersebut menjelaskan bahwa yang menjadi faktor berkurangnya masalah adalah dengan adanya peningkatan kesadaran maka meningkat juga support system yang dihasilkan dari kontribusi masyarakat pada bidangnya masing-masing. Dimulai dari unit terkecil dalam lingkungan sosial, yaitu melalui individu dan berlanjut kepada lingkungan komunitas dari individu tersebut.

"Ambil contoh kita bisa kasih masukan kepada B, C, D, dan ternyata mereka temannya $\mathrm{A}$, dan mereka yang statusnya sebagai teman pasti akan lebih didengarkan daripada kita sebagai stranger di mata A, jadi selain bisa kasih tahu orang secara langsung, bisa bikin rantai komunikasi." (wawancara GV).

Pernyataan GV tersebut menunjukkan bahwa individu yang terpapar dengan kampanye \#JMDP akan membawa informasi yang ada kepada lingkungan sosialnya, seperti penjelasan di atas dengan menggunakan lingkungan pertemanan sebagai contoh. Maka dari pernyataan GV mendukung apa yang sudah dilakukan oleh ALZI melalui pernyataan PT, dengan bergerak dari unit terkecil dalam lingkungan sosial, yaitu individu. 
Pandangan lain diberikan oleh AV agar kampanye dapat mengurangi masalah dari segi kesadaran, seperti yang dijelaskan dalam hasil wawancara dengan menggunakan media, seperti guidebook agar memudahkan masyarakat untuk mencari informasi mengenai demensia tanpa harus datang ke caregivers meeting, karena keterbatasan dalam akses menuju ke tempat pertemuan. Selain itu, dari sisi komunikasi, ALZI juga perlu melakukan media partnership dengan beberapa media untuk mendapat jangkauan yang baik seperti yang telah dibahas dalam strategi kampanye. $\mathrm{AH}$ berpendapat bahwa dengan adanya jangkauan dari media yang tepat maka dapat membantu mengurangi masalah dari segi kesadaran.

Pembangunan kesadaran diawali dengan mematahkan stigma negatif terhadap demensia, seperti yang sudah dijelaskan pada strategi kampanye \#JMDP dengan menggunakan grabbers "Jangan Maklum Dengan Pikun".

"Kalau mendengar \#JMDP bahasanya sederhana, kemudian orang-orang pasti langsung bertanya "kenapa kok kita enggak bisa memaklumi pikun?" dari situlah muncul beberapa pertanyaan atau curiosities orang-orang itu untuk mencari informasi lebih lanjut, nah dari situlah kita mulai mengedukasi kalau gak wajar lhoo udah tua pikun, jadi kalau dengan adanya satu kalimat yang sederhana, karna ada kata-kata powerful "Jangan Maklum", menurut saya ketika kata-kata ini berdiri sendiri mereka akan tetap cukup powerful dan memiliki impact apalagi kalau mereka digabung menjadi satu kesatuan." (wawancara PT).
Berdasarkan penjelasan tersebut, maka dapat dinyatakan kata "Jangan Maklum Dengan Pikun" akan membentuk adanya keingintahuan masyarakat mengenai isu demensia. Rasa keingintahuan akan merujuk kepada peningkatan kesadaran yang disertai dengan edukasi mengenai pikun sebagai suatu hal yang sudah dianggap tidak normal. Selain menggunakan grabbers dalam konten pesan, maka faktor kedua yang digunakan dalam membangun kesadaran adalah dengan konsistensi penggunaan \#JMDP seperti yang sudah dijelaskan dalam strategi kampanye.

Selain dari program dan bentuk kampanye, pembangunan kesadaran juga dilakukan melalui program summer school dapat dilihat pada gambar 2, sesi pembangunan kesadaran ditempatkan pada sesi terakhir. Menurut PT, penempatan sesi peningkatan kesadaran pada posisi terakhir sudah tepat dengan alasan,

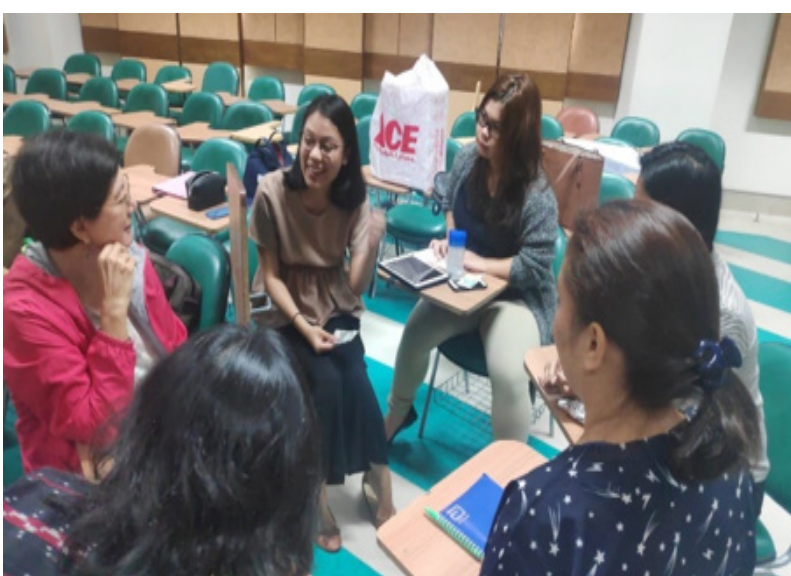

Sumber: Dokumentasi peneliti, 2019

Gambar 2 Sesi Diskusi pada Program Summer School FK UAJ 
peserta Summer School harus terlebih dahulu mengetahui apa itu demensia, hal ini disesuaikan dengan target audiens dari Summer School yang merupakan kalangan mahasiswa dan akademisi yang peduli terhadap isu demensia. Penempatan dalam posisi terakhir dinilai sebagai postdiagnostic-support terhadap penanganan isu demensia dengan memberikan programprogram yang mendukung jika terdapat salah satu anggota keluarga yang terkena demensia.

"Kenapa ALZI yang raising awareness kita taruh dipaling akhir harapannya ketika sudah mendapatkan semua materi tentang demensia ini selama 3 minggu, mereka sudah siap untuk raise awareness, harapannya di akhir itu sebagai penutup bisa menjadi seperti penutup sekaligus pengantar bagi mereka (peserta) untuk menyebarkan pesan yang benar soal demensia kita taruh di akhir karna itu." (wawancara dr. T).

Kutipan wawancara tersebut menyatakan bahwa pandangan PT didukung dengan pandangan dari dr. $\mathrm{T}$ yang menyatakan penempatan sesi ALZI pada tahapan terakhir sudah tepat karena panitia Summer School mengharapkan peserta dapat membantu meningkatkan kesadaran setelah terpapar di minggu pertama mengenai demensia dan ditutup dengan cara untuk menyebarkan kesadaran, dr.

T menyampaikan bahwa sesi ALZI merupakan penutup dan pembuka bagi peserta untuk ke depannya.

Pandangan PT dan dr. T didukung dari pernyataan dr. O melalui hasil wawancara yang menyatakan mengenai sesi peningkatan kesadaran secara spesifik manfaat dari peran PT dalam sesi terakhir, sebagai berikut:

"Yang dilakukan ka PT adalah memberikan contoh-contoh usaha yang telah dilakukan oleh ALZI dalam menyebarkan itu, jadi minimal yang dapat dilakukan oleh peserta adalah mengikuti cara-cara ka PT dalam melakukan hal-hal tertentu untuk membantu menyebarkan awareness di masyarakat, itu makanya menjadi penutup karena sekaligus memberikan contoh bagi pesertanya." (wawancara dr. O).

Berdasarkan pertanyaan tersebut, dengan adanya PT sebagai pembicara pada sesi peningkatan kesadaran, maka dapat memberikan contoh mengenai upaya yang sudah dilakukan oleh organisasi dalam menangani isu di lapangan. dr. O menyatakan harapannya bagi peserta adalah dengan adanya sesi peningkatan kesadaran, maka para peserta dapat menjadi mercusuar atau agen-agen dari kampanye \#JMDP. Selain itu, dr. T dalam hasil wawancara juga menjelaskan peran kampanye \#JMDP dalam membangun kesadaran melalui sesi peningkatan kesadaran adalah untuk menjadi jembatan antara materi yang dipelajari dalam kelas dengan praktik yang terjadi di lapangan. Selain menjadi jembatan, peran kampanye \#JMDP dalam sesi tersebut adalah untuk memberikan networking bagi para peserta untuk terhubung dengan ALZI supaya dapat berkontribusi dengan baik. Penempatan sesi 


\section{Tabel 1 Rangkuman Hasil Analisis}

Strategi Kampanye

Model Kampanye:

Model Ostergaard
Strategi kampanye Alzi bersifat proactive dan reactive, bergantung tujuan dari kampanye. Proactive untuk tujuan mempromosikan mengenai awareness terhadap publik dan reactive ketika bertujuan untuk meminimalisir stigma negatif yang terbentuk dalam pemikiran masyarakat.

Tahapan dalam manajemen kampanye sesuai dengan model Ostergaard:

-Issue: penyusunan strategi dimulai dari isu yang ingin diselesaikan oleh organisasi. Isu terbentuk akibat adanya gap yang luas mengenai pemahaman publik akan pentingnya gejala awal demensia yaitu pikun.

-Campaign: pada tahap kampanye maka disusun dengan menetapkan tujuan yaitu meningkatkan awareness agar meningkat juga support system yakni para enablers yang mendukung program kampanye. Kedua, kemasan pesan yang menarik perhatian, ketiga saluran komunikasi yang disesuaikan dengan target audience, keempat adalah tata pelaksanaan kampanye melalui program summer school.

-Attidues \& Behaviour: Perubahan sikap yang terbentuk dari segi peningkatan knowledge adalah dengan para peserta tahu bagaimana cara memperlakukan para ODD dengan baik.

-Reduced Problem: Kampanye \#JMDP dapat mengurangi masalah dari segi awareness, ditandai dengan individu dari peserta summer school dapat menjadi agen kampanye yang membawan informasi kepada lingkunganya masing-masing.

Pembangunan Awareness

Terdapat dua hal yang dilakukan Alzi dalam membangun awareness mengenai isu demensia sebagai berikut:

-Konsistensi dari penggunaan \#JMDP dalam setiap kegiatan kampanye yang dilakukan oleh Alzi, seperti menggunakan \#JMDP pada kaos, leaflet, dan materi-materi presentasi.

-Penempatan sesi raising awareness oleh Alzi pada posisi terakhir dalam program summer school. Dampak yang dihasilkan adalah menjadi sesi tersebut menjadi penutup sekaligus pembuka bagi para peserta untuk dapat menerapkan atau membagikan informasi yang sudah didapat selama program summer school. Individu yang terpapar akan membawa informasi tersebut kepada lingkungan dari masing-masing individu. 
peningkatan kesadaran dengan ALZI pada sesi terakhir dapat mempersempit kesenjangan yang pada awalnya dimiliki oleh peserta secara luas dengan pemahaman di awal mengenai demensia lalu dipersempit dengan kondisi dalam lapangan melalui presentasi materi yang dilakukan oleh ALZI dengan kampanye \#JMDP.

\section{SIMPULAN}

Berdasarkan hasil analisis, maka terdapat beberapa kesimpulan pada penelitian ini. Pertama, bentuk dari strategi kampanye \#JMDP bersifat proactive dan reactive strategy yang bergantung pada tujuan dari kampanye. Proactive untuk tujuan mempromosikan mengenai kesadaran terhadap publik dan reactive ketika bertujuan untuk meminimalisir stigma negatif yang terbentuk dalam pemikiran masyarakat.

Kedua, berdasarkan hasil analisis dengan menggunakan model Ostergaard, ALZI melakukan penyusunan strategi dimulai dari isu yang ingin diselesaikan oleh organisasi. Isu terbentuk akibat adanya kesenjangan yang luas mengenai pemahaman publik akan pentingnya gejala awal demensia, yaitu pikun. Tahap berikutnya, campaign, kampanye disusun dengan menetapkan tujuan yaitu meningkatkan kesadaran agar meningkat juga support system, yakni para enablers yang mendukung program kampanye. Selain itu, kampanye harus memiliki kemasan pesan yang menarik perhatian, saluran komunikasi yang disesuaikan dengan target audiens, dan tata pelaksanaan kampanye melalui program summer school. Pada tahap attidues \& behaviour, perubahan sikap yang terbentuk dari segi peningkatan knowledge adalah dengan para peserta tahu bagaimana cara memperlakukan para ODD dengan baik. Tahap selanjutnya, reduced problem menyatakan bahwa kampanye \#JMDP dapat mengurangi masalah dari segi kesadaran, ditandai dengan individu dari peserta Summer School dapat menjadi agen kampanye yang membawa informasi ke lingkungannya masing-masing.

Kesimpulan ketiga, ALZI membangun kesadaran mengenai isu demensia melalui konsistensi dari penggunaan \#JMDP dalam setiap kegiatan kampanye yang dilakukan oleh ALZI, seperti menggunakan \#JMDP pada kaos, leaflet, dan materi-materi presentasi. Konsistensi dalam menggunakan kalimat “Jangan Maklum Dengan Pikun" dalam setiap atribut dan aktivitas kampanye berdampak pada semakin kuatnya kesadaran yang terbangun dan juga memperkuat positioning ALZI sebagai organisasi yang memiliki kepedulian terhadap isu demensia. Selain itu, terdapat penempatan sesi peningkatan kesadaran oleh ALZI pada posisi terakhir dalam program summer school. Hasil yang diperoleh adalah sesi tersebut menjadi penutup sekaligus pembuka bagi 
para peserta untuk dapat menerapkan atau membagikan informasi yang sudah diperoleh selama program summer school. Dengan hal tersebut, maka peserta dinilai sudah mampu menjadi agen kampanye pada lingkungan sosial masing-masing.

Terdapat beberapa saran pada penelitian ini, baik saran akademis maupun saran praktis. Pada saran akademis, peneliti selanjutnya disarankan dapat melakukan penelitian dengan metode dan fokus penelitian yang berbeda untuk memperkaya kajian. Selain itu, metode dan fokus penelitian yang berbeda dapat memperdalam kajian dikarenakan penelitian ini hanya menggunakan analisis deskriptif. Pada saran praktis, peneliti menyarankan bagi organisasi Alzheimer Indonesia untuk melanjutkan kampanye \#JMDP serta membangun kesadaran masyarakat terhadap isu demensia. ALZI disarankan untuk membangun aliansi dengan media-media online yang sesuai dengan tujuan kampanye. Tujuan dari aliansi tersebut adalah untuk mendapatkan media coverage yang dibutuhkan dalam meningkatkan paparan bagi masyarakat luas sehinga nantinya akan berdampak pada meningkatnya kesadaran. Peneliti juga menyarankan bagi ALZI untuk melakukan tahap-tahap selanjutnya setelah masyarakat melewati fase screening dengan kampanye \#JMDP. Format guidebook dapat menjadi salah satu referensi dalam memberikan informasi yang lebih memadai agar masyarakat yang bukan orang dengan demensia (non-ODD) dan masyarakat yang merupakan orang dengan demensia (ODD) dengan tujuan agar masyarakat tetap memiliki kesadaran akan pentingnya isu demensia serta dapat mempertahankan kualitas hidup yang baik bagi para ODD.

\section{DAFTAR PUSTAKA}

Adhabi, E. A. R., \& Anozie, C. B. L. (2017). Literature review for the type of interview in qualitative research. International Journal of Education, 9(3), 86. https://doi. org/10.5296/ije.v9i3.11483

Chandra, A. L. (2014). Strategi kampanye "breast cancer awareness month". Jurnal E-Komunikasi, 2(1). https://doi.org/http:// publication.petra.ac.id/index.php/ilmukomunikasi/issue/view/74

Gregory, A. (2010). Planning \& managing public relations campaigns (third edit). London: Kogan Page Ltd.

Jackson, R. L., Drummond, D. K., \& Camara, S. (2007). What is qualitative research? Qualitative Research Reports in Communication, 8(1), 21-28. https://doi. org/10.1080/17459430701617879

kitabisa.com. (n.d.). https://kitabisa.com/ campaign/melawanpikun. Diakses pada 28 September 2019.

Komariah, K., Perbawasari, S., Nugraha, A. R., \& Budiana, H. R. (2013). Pola komunikasi kesehatan dalam pelayanan dan pemberian informasi mengenai penyakit tbc pada puskesmas di Kabupaten Bogor. Jurnal Kajian Komunikasi, 1(2), 173-185. https:// doi.org/10.24198/jkk.vol1n2.7

Lasari, Y., Dewi, S., \& Diahloka, C. (2015). 
Strategi komunikasi duta hiv/aids dalam kampanye hiv/aids di kalangan transgender pada ikatan waria Malang. Jurnal Ilmu Sosial Dan Ilmu Politik Universitas Tribhuwana Tunggadewi, 4(3), 42416. https://publikasi.unitri.ac.id/index.php/ fisip/article/view/129

Maharani, E. (2017). WHO : jumlah penderita demensia berlipat. https://www. republika.co.id/berita/gaya-hidup/infosehat/17/12/09/p0ob77335-who-jumlahpenderita-demensia-berlipat. Diakses pada 16 September 2019.

Michaelson, D., Wright, D., \& Stacks, D. (2012). Evaluating efficacy in public relations / corporate communication programming: Towards establishing standards of campaign performance. Public Relations Journal, 6(5), 1-25. https://www.instituteforpr.org/ wp-content/uploads/Michaelson-WrightStacks-PR-Journal-2012-Vol-6-No-5.pdf

Mulyadi, M. (2013). Riset desain dalam metodologi penelitian. Jurnal Studi Komunikasi Dan Media, 16(1), 71. https:// doi.org/10.31445/jskm.2012.160106

Mulyana, D. (2013). Metodologi penelitian kualitatif. Bandung: PT Remaja Rosdakarya.

Nassaji, H. (2015). Qualitative and descriptive research: Data type versus data analysis. Language Teaching Research, 19(2), 129-132. https://doi. org/10.1177/1362168815572747

Natow, R. S. (2019). The use of triangulation in qualitative studies employing elite interviews. Qualitative Research, 20(2), 160-173. https://doi. org/10.1177/1468794119830077
Nilamsari, N. (2014). Memahami Studi Dokumen Dalam Penelitian Kualitatif. Wacana, 13(2), 177-181. https://journal. moestopo.ac.id/index.php/wacana/article/ view/143/88

Noble, H., \& Heale, R. (2019). Triangulation in research, with examples. EvidenceBased Nursing, 22(3), 67-68. https://doi. org/10.1136/ebnurs-2019-103145

Putri, N. E., Hakim, N., \& Yamin, M. (2016). Ecologicall footprint and biocapacity analysis for flooding prevention in South Sumatera. Jurnal Mimbar, 32(1), 58-64. https://media.neliti.com/media/ publications/157872-EN-ecologicallfootprint-and-biocapacity-an.pdf

Smith, R. (2014). Public relations the basics. New York: Routledge.

Smith, R. D. (2002). Strategic for planning public relations. London: Lawrence Earlbaum Associate.

Suriastini, N., Turana, Y., Witoelar, F., Supraptilah, B., Wicaksono, T., \& Dwi, E. (2016). Angka prevalensi demensia: perlu perhatian kita semua. SurveyMETER, 1-4. https://doi.org/10.4210/ssee.pbs.2009.0001

Thomas, R. K. (2006). Health communication. New York: Springer.

Venus, A. (2009). Manajemen kampanye. Bandung: Simbiosa Rekatama Media. www.alzi.or.id. (n.d.). https://www.alzi.or.id/ atma-jaya-alzi-co-working-space-atzicenter. Diakses pada 14 September 2019.

www.kemkes.go.id. https://www.kemkes.go.id/ article/view/19070500004/indonesiamasuki-periode-aging-population.html. Diakses pada tanggal 14 September 2019. 